\title{
Insulation-Affecting Factors of Low-Emissivity Insulation
}

\author{
Young Cheol Kwon ${ }^{1}$ and Kyung Min Kim ${ }^{2}$ \\ ${ }^{1}$ Dept. Of Architecture, Halla Univ., Wonju, Gangwon, 220-712, South Korea \\ ${ }^{2}$ Research Institute, Ilsin Company, Gyungsan, Gyungbuk, 712-861, South Korea \\ ${ }^{1}$ yckwon@halla.ac.kr, ${ }^{2}$ km.kim@low-e.co.kr
}

\begin{abstract}
Low-Emissivity Insulation has enclosed reflective air spaces between aluminum foils that have very low emissivity. The reflective air spaces are composed of optimum-sized air cells, which are enclosed by polyethylene foam. The critical difference between LowEmissivity Insulation and conventional reflective insulation is the presence of a honeycomb structure formed from polyethylene that serves as the core material. Low-Emissivity Insulation has a foil surface emissivity of 0.04 with enclosed air cells between foils. Its core material is polyethylene foam with 35 times expansion, which is expanded to make air cells. The enclosed air cells with foil reduce convective and radiative heat transfer. To verify the high efficiency of Low-Emissivity Insulation, it was tested by an accredited laboratory designated by the Korean government. Comprehensive thermal transmittance tests were conducted for the Low-Emissivity Insulation of specimens of various thicknesses. The thicknesses of the specimens were 10,20,30, 40, 50, 60, 80, and 100mm. Based on the test results, its insulation-affecting factors were investigated using a trialand-error method.
\end{abstract}

Keywords: Low-Emissivity Insulation, Overall Thermal Transmittance, Thermal Resistance, Insulation-affecting Factors

\section{Introduction}

Low-Emissivity Insulation is a multilayer product consisting of layers of aluminum foil and a honey-comb structure produced from polyethylene foam. The resulting structure creates reflective airspaces within the cavity that reduce radiant heat transfer and heat flow by convection. The use of aluminum foil ensures a minimum 95\% reduction in radiation across the enclosed regions.

Low-Emissivity Insulation has a foil surface emissivity of 0.04 with enclosed air cells between foils. Its core material is polyethylene foam with 35 times expansion, which is expanded to make air cells. The enclosed air cells with foil reduce convective and radiative heat transfer.[1]

Figure 1 shows a 20mm-thick Low-Emissivity Insulation structure.

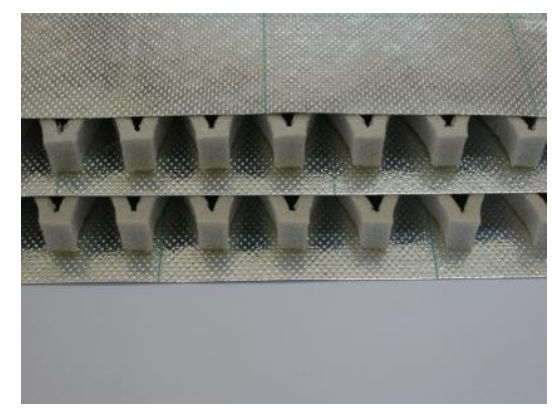

Figure 1. 20mm-Thick Low-Emissivity Insulation 
As Low-Emissivity Insulation is not a homogeneous material, it is impossible to measure its thermal conductivity. Its insulating performance is measured by a Hot Box Test in accordance with ISO 8990(Thermal Insulation -- Determination of steady-state thermal transmission properties -- Calibrated and guarded hot box).

It is necessary to verify the thermal resistance of its constitution materials to improve the insulating performance of Low-Emissivity Insulation.

This paper discusses the insulating characteristics of Low-Emissivity Insulation depending on heat transfer paths and materials. Low-Emissivity Insulation is composed of separated reflective air cells and polyethylene foam partitions between low-emissivity aluminum foils as shown in $<$ Fig. 1 $1>$. This means that Low-Emissivity Insulation is divided into two parts according to the heat transfer paths such as reflective air cell and conductive polyethylene foam. Comprehensive thermal transmittance tests were conducted for the Low-Emissivity Insulation of specimens of various thicknesses. The thicknesses of the specimens were 10, 20,30, 40,50,60,80, and 100mm. Based on the test results, its insulation-affecting factors were investigated using a trial-and-error method.

\section{Insulating Performance of Low-Emissivity Insulation}

To verify the high efficiency of Low-Emissivity Insulation, it was tested by an accredited laboratory designated by the Korean government. Comprehensive thermal transmittance tests were conducted for the Low-Emissivity Insulation of specimens of various thicknesses. The thicknesses of the specimens were 10, 20, 30, 40, 50, 60, 80, and $100 \mathrm{~mm}$. The comprehensive thermal transmittance test was conducted in accordance with ISO 8990 (Thermal Insulation -- Determination of Steady-State Thermal Transmission Properties -- Calibrated and Guarded Hot Box). $\quad<$ Fig. $2>$ shows a drawing of the test specimen.
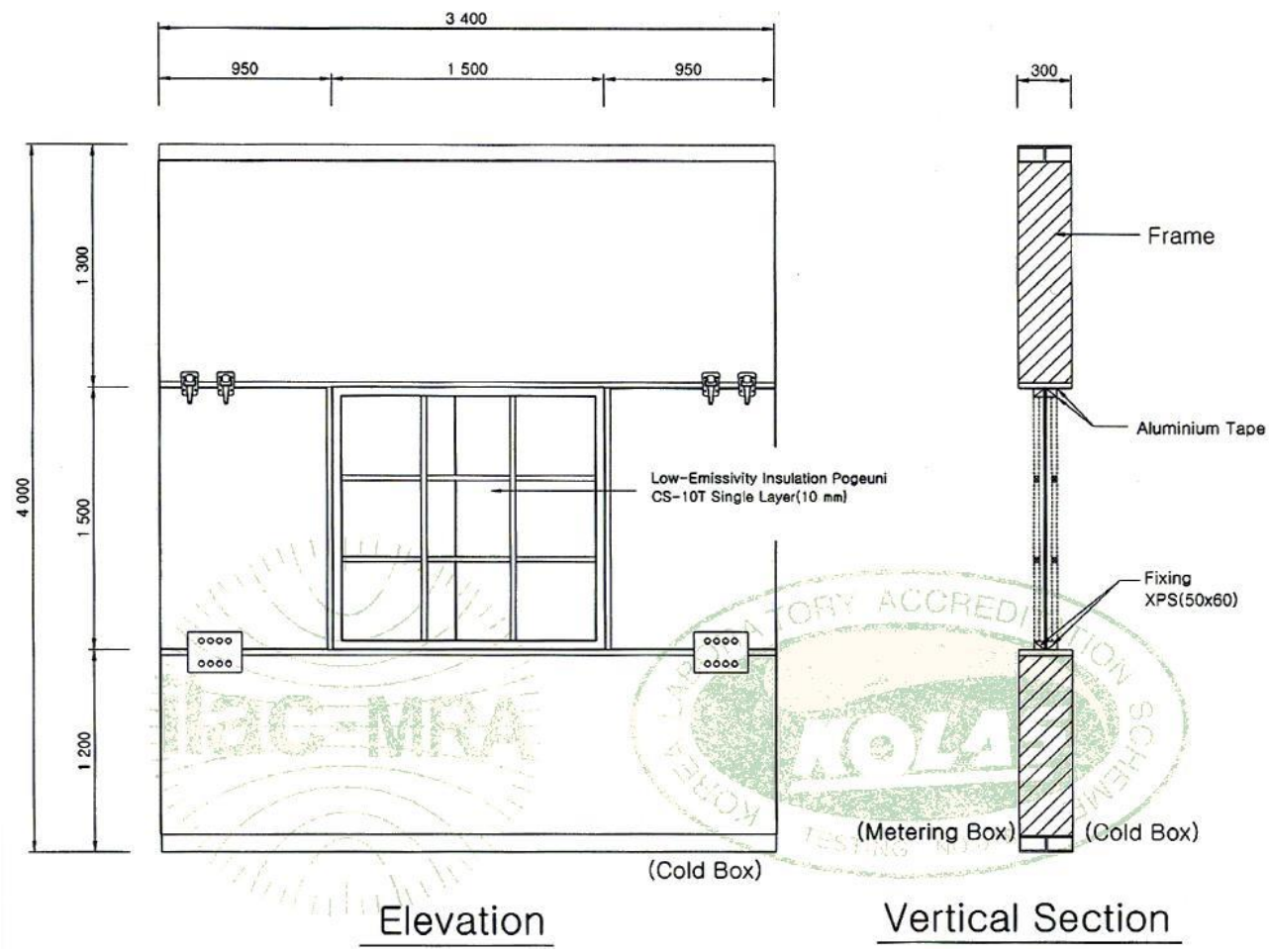

Figure 2. Drawing of the Test Specimen 
The test specimen size is $1500 \mathrm{~mm} * 1500 \mathrm{~mm}$. <Fig. $3>$ shows the locations of the temperature sensors.

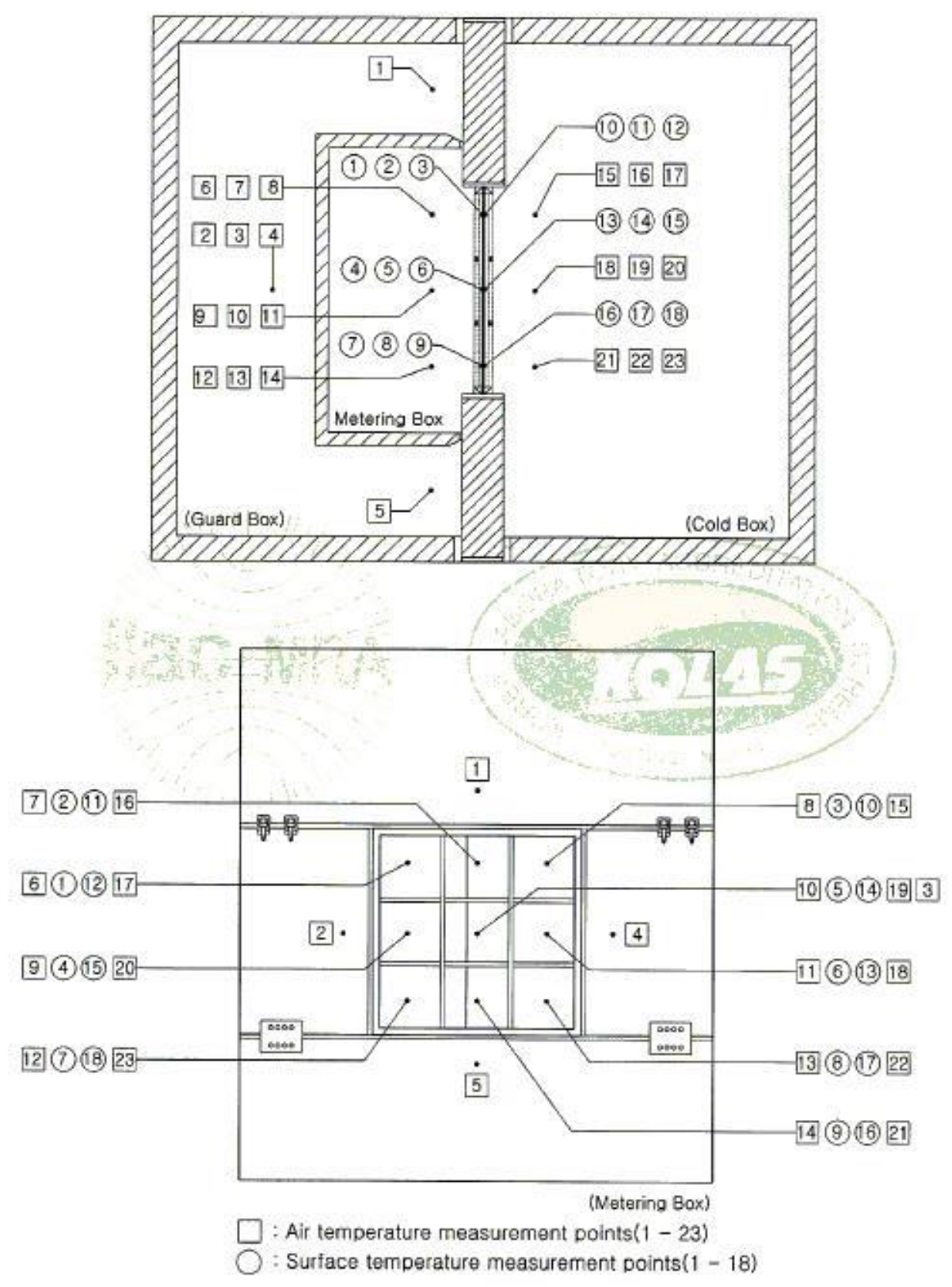

Figure 3. Location of the Temperature Sensors

To get more accurate measurement results, three temperature sensors were located at each point. The temperature at each point was determined by averaging the three measured values.

The hot box facility was calibrated using a polystyrene foam board whose thermal conductivity had been acquired from a heat flow meter apparatus test at an accredited laboratory designated by KOLAS, the Korea Laboratory Accreditation Scheme.

Tests were conducted with a hot region temperature of $20^{\circ} \mathrm{C}$ and a cold region temperature of $0^{\circ} \mathrm{C}$. The heat flow rate from the hot region to the cold region is determined from energy input to the hot region as in the case with ASTM C 1363. The overall thermal transmittance was calculated after steady-state conditions had been 
achieved. Data were recorded three times every hour and averaged. The overall thermal transmittance(U) can be obtained from $<$ Equation 1>.[2]

$$
\mathrm{U}=1 / \mathrm{R}=\mathrm{Q} /\left((\mathrm{Th}-\mathrm{Tc})^{*} \mathrm{~A}\right)
$$

$\mathrm{U}$ : Overall thermal transmittance $\left(\mathrm{W} / \mathrm{m}^{2} \mathrm{~K}\right)$

$\mathrm{R}$ : Overall thermal resistance $\left(\mathrm{m}^{2} \mathrm{~K} / \mathrm{W}\right)$

$\mathrm{Q}$ : Supplied heat $(\mathrm{W})$

Th: Temperature of hot region $\quad\left({ }^{\circ} \mathrm{C}\right)$

Tc: Temperature of cold region $\quad\left({ }^{\circ} \mathrm{C}\right)$

A : Area of specimen $\left(\mathrm{m}^{2}\right)$

Test results are shown in $<$ Table $1>$.

Table 1. Overall Thermal Transmittance and Thermal Resistance of LowEmissivity Insulation

\begin{tabular}{c|c|c|c}
\hline \multirow{2}{*}{$\begin{array}{c}\text { Thickness } \\
(\mathrm{mm})\end{array}$} & $\begin{array}{c}\text { Overall Thermal } \\
\text { Transmittance } \\
\left(\mathrm{W} / \mathrm{m}^{2} \mathrm{~K}\right)\end{array}$ & $\left(\mathrm{m}^{2} \mathrm{~K} / \mathrm{W}\right)$ & $\left(\mathrm{ft}^{2}{ }^{\circ} \mathrm{Fhr} / \mathrm{Btu}\right)$ \\
\cline { 3 - 4 } 10 & 1.12 & 0.89 & 5.10 \\
20 & 0.55 & 1.82 & 10.3 \\
30 & 0.45 & 2.22 & 12.6 \\
40 & 0.32 & 3.13 & 17.8 \\
50 & 0.27 & 3.70 & 21.0 \\
60 & 0.22 & 4.55 & 25.8 \\
80 & 0.19 & 5.26 & 29.9 \\
100 & 0.14 & 7.14 & 40.5 \\
\hline
\end{tabular}

$<$ Table $1>$ shows that a $100 \mathrm{~mm}$ thick Low-Emissivity Insulation can meet the overall thermal transmittance of walls and roofs of Passive Houses which is below $0.15 \mathrm{~W} / \mathrm{m}^{2} \mathrm{~K} .[3]$

$<$ Fig. $4>$ shows the required thickness of various insulations to meet the overall thermal transmittance of Passive Houses of $0.15 \mathrm{~W} / \mathrm{m}^{2} \mathrm{~K}$.

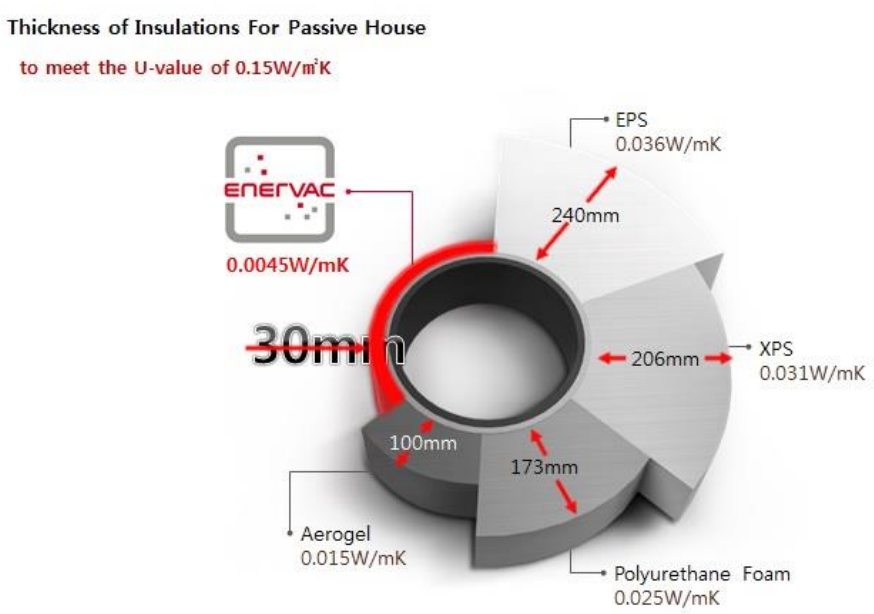

Figure 4. Required Thickness of Various Insulations for Passive Houses 
While as thick as $240 \mathrm{~mm}$ of EPS, whose thermal conductivity is $0.036 \mathrm{~W} / \mathrm{mK}$, should be used, as thick as $30 \mathrm{~mm}$ of Enervac, which is a kind of a vacuum insulation panel, can be used as insulation for Passive Houses.[4] From $<$ Table $1>$ and $<$ Fig. $4>$, we can assume that Low-Emissivity Insulation has the same insulating performance as Aerogel.

\section{Insulation-Affecting Factors of Low-Emissivity Insulation}

\subsection{Classification of Insulation-Affecting Factors}

The thermal resistance of Low-Emissivity Insulation can be expressed as the sum of the resistance of air films, conductive heat resistance, and thermal resistance of reflective air cells.

$$
\begin{aligned}
& \mathrm{R}_{\text {total }}=\mathrm{R}_{\text {film }}+\mathrm{R}_{\mathrm{c}}+\mathrm{R}_{\text {air }} \\
& \mathrm{R}_{\text {total }} \text { Thermal resistance of Low-Emissivity Insulation }\left(\mathrm{m}^{2} \mathrm{~K} / \mathrm{W}\right) \\
& \mathrm{R}_{\mathrm{film}}: \text { Resistance of air films }\left(\mathrm{m}^{2} \mathrm{~K} / \mathrm{W}\right) \\
& \mathrm{R}_{\mathrm{c}}: \text { Conductive heat resistance }\left(\mathrm{m}^{2} \mathrm{~K} / \mathrm{W}\right) \\
& \mathrm{R}_{\text {air }}: \text { Thermal resistance of reflective air cells }\left(\mathrm{m}^{2} \mathrm{~K} / \mathrm{W}\right)
\end{aligned}
$$

\begin{tabular}{|c|c|c|c|c|c|c|c|c|}
\hline & \multirow{4}{*}{$\begin{array}{l}\text { Surface } \\
\text { Type }\end{array}$} & \multirow{4}{*}{$\begin{array}{l}\text { Direction } \\
\text { of } \\
\text { Heat Flow }\end{array}$} & \multicolumn{6}{|c|}{ Emissivity of Surface } \\
\hline & & & \multirow{2}{*}{\multicolumn{2}{|c|}{$\begin{array}{c}\text { Non-Reflective } \\
\varepsilon=0.90\end{array}$}} & \multicolumn{4}{|c|}{ Reflective } \\
\hline & & & & & \multicolumn{2}{|c|}{$\varepsilon=0.20$} & \multicolumn{2}{|c|}{$\varepsilon=0.05$} \\
\hline & & & hi $^{*}$ & $\mathrm{R}^{* *}$ & hi & $\mathrm{R}$ & hi & $\mathrm{R}$ \\
\hline \multirow{5}{*}{$\begin{array}{l}\text { Static } \\
\text { Air }\end{array}$} & Horizontal & $\mathrm{Up}$ & 9.26 & 0.11 & 5.17 & 0.19 & 4.32 & 0.23 \\
\hline & $45^{\circ}$ Slope & Up & 9.09 & 0.11 & 5.00 & 0.20 & 4.15 & 0.24 \\
\hline & Vertical & Horizontal & 8.29 & 0.12 & 4.20 & 0.24 & 3.35 & 0.30 \\
\hline & $45^{\circ}$ Slope & Down & 7.50 & 0.13 & 3.41 & 0.29 & 2.56 & 0.39 \\
\hline & Horizontal & Down & 6.13 & 0.16 & 2.10 & 0.48 & 1.25 & 0.80 \\
\hline \multirow{3}{*}{$\begin{array}{l}\text { Dynamic } \\
\text { Air }\end{array}$} & \multirow{3}{*}{\multicolumn{2}{|c|}{$\begin{array}{l}\text { Winter Air Velocity }(6.7 \mathrm{~m} / \mathrm{s}) \\
\text { Summer Air Velocity }(3.4 \mathrm{~m} / \mathrm{s})\end{array}$}} & ho* & $\mathrm{R}$ & ho & $\mathrm{R}$ & ho & $\mathrm{R}$ \\
\hline & & & 34.0 & 0.03 & \multirow{2}{*}{\multicolumn{2}{|c|}{ - }} & \multirow{2}{*}{\multicolumn{2}{|c|}{ - }} \\
\hline & & & 22.7 & 0.04 & & & & \\
\hline
\end{tabular}

\subsubsection{Resistance of Air Films}

The resistance of air films is determined by the emissivity of surfaces, air velocity, and heat flow direction. It ranges from 0.03 to 0.80 as shown in $<$ Table $2>[5]$.

Table 2. Resistance of Air Films

\subsubsection{Conductive Heat Resistance}

The conductive heat resistance can be determined by dividing the thickness of the polyethylene foam by its apparent thermal conductivity.

The core material of Low-Emissivity Insulation is polyethylene foam whose thermal conductivity is assumed to range from $0.03 \sim 0.07 \mathrm{~W} / \mathrm{mK}$.

\subsubsection{Resistance of Reflective Air Cells}

The resistance of reflective air cells is composed of the sum of radiative heat resistance and the convective heat resistance of reflective air cells of Low-Emissivity Insulation. 


\subsection{Analysis of the Contribution Rate of the Insulation-Affecting Factors of Low- Emissivity Insulation}

The test results of the comprehensive thermal transmittance of Low-Emissivity Insulation according to its thickness can be plotted as shown in $<$ Fig. $5>$.

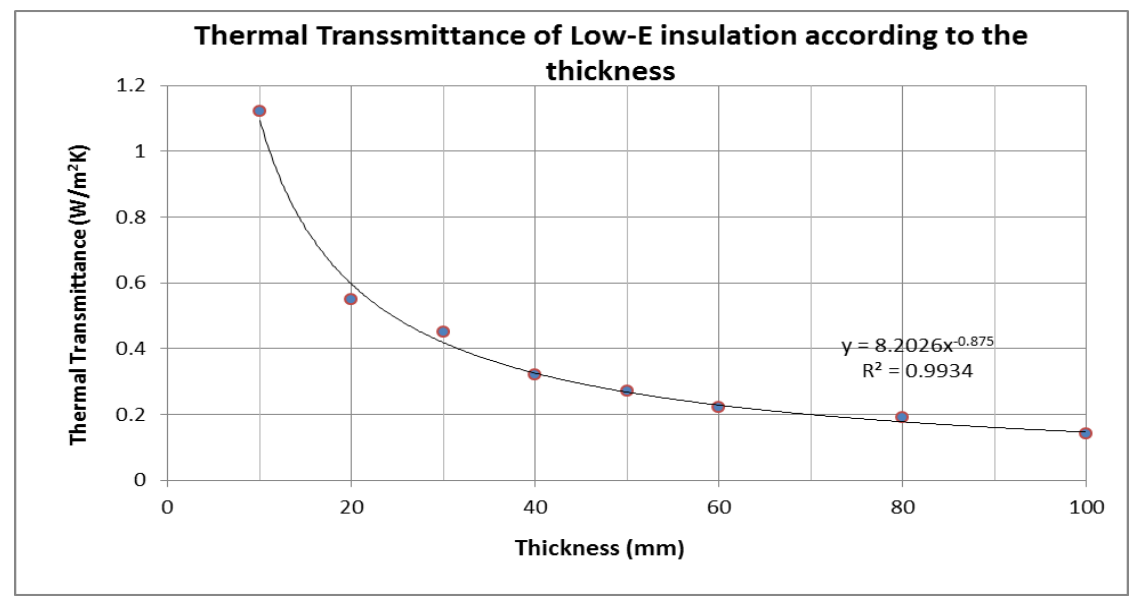

\section{Figure 5. Test Results of the Comprehensive Thermal Transmittance of Low-Emissivity Insulation}

Based on the test results of the comprehensive thermal transmittance of Low-Emissivity Insulation shown in $\langle$ Fig. $5>$, its insulating characteristics were investigated using a trial-and-error method.[6] As shown in $<$ Equation 2 $>$, the contribution rate of the affecting factors such as the resistance of air films, conductive heat resistance, and thermal resistance of reflective air cells was extracted.

$<$ Table $3>$ shows an example of the extracted resistances of the affecting factors to match the expected thermal transmittance with the test results.

Table 3. Example of the Extracted Resistances of the Affecting Factors

\begin{tabular}{|c|c|c|c|c|c|c|c|}
\hline \multirow[b]{2}{*}{$\begin{array}{c}\text { Thickness } \\
\text { of } \\
\text { Insulation } \\
(\mathrm{mm})\end{array}$} & \multicolumn{2}{|c|}{$\begin{array}{c}\text { Thermal } \\
\text { Transmittance } \\
\left(\mathrm{W} / \mathrm{m}^{2} \mathrm{~K}\right)\end{array}$} & \multicolumn{5}{|c|}{ Affecting Factor } \\
\hline & $\begin{array}{c}\text { Test } \\
\text { Result }\end{array}$ & $\begin{array}{c}\text { Expected } \\
\text { Result }\end{array}$ & $\begin{array}{c}\text { Extracted } \\
\text { Resistance } \\
\text { of Air } \\
\text { Films } \\
\left(\mathrm{m}^{2} \mathrm{~K} / \mathrm{W}\right)\end{array}$ & $\begin{array}{c}\text { Assumed } \\
\text { Thermal } \\
\text { Conductivity } \\
(\mathrm{W} / \mathrm{mK})\end{array}$ & $\begin{array}{c}\text { Extracted } \\
\text { Thermal } \\
\text { Resistance } \\
\text { of 10mm- } \\
\text { Thick } \\
\text { Reflective } \\
\text { Air Cells } \\
\left(\mathrm{m}^{2} \mathrm{~K} / \mathrm{W}\right)\end{array}$ & $\begin{array}{l}\text { Number } \\
\text { of } 10 \mathrm{~mm}- \\
\text { Thick } \\
\text { Insulation }\end{array}$ & $\begin{array}{c}\text { Expected } \\
\text { Thermal } \\
\text { Resistance } \\
\left(\mathrm{m}^{2} \mathrm{~K} / \mathrm{W}\right)\end{array}$ \\
\hline 50 & 0.27 & 0.270 & 0.360 & 0.050 & 0.470 & 5 & 3.688 \\
\hline
\end{tabular}

To extract the most suitable resistance of each affecting factor, assumed values were input until the expected thermal resistance matched with the test results.

Through the trial-and-error method, the most suitable values of the resistances of the affecting factors that match the expected thermal transmittance with the test results were extracted. The extracted values according to the thicknesses are shown in $\langle$ Fig. 6> and $\langle$ Table 4>. 


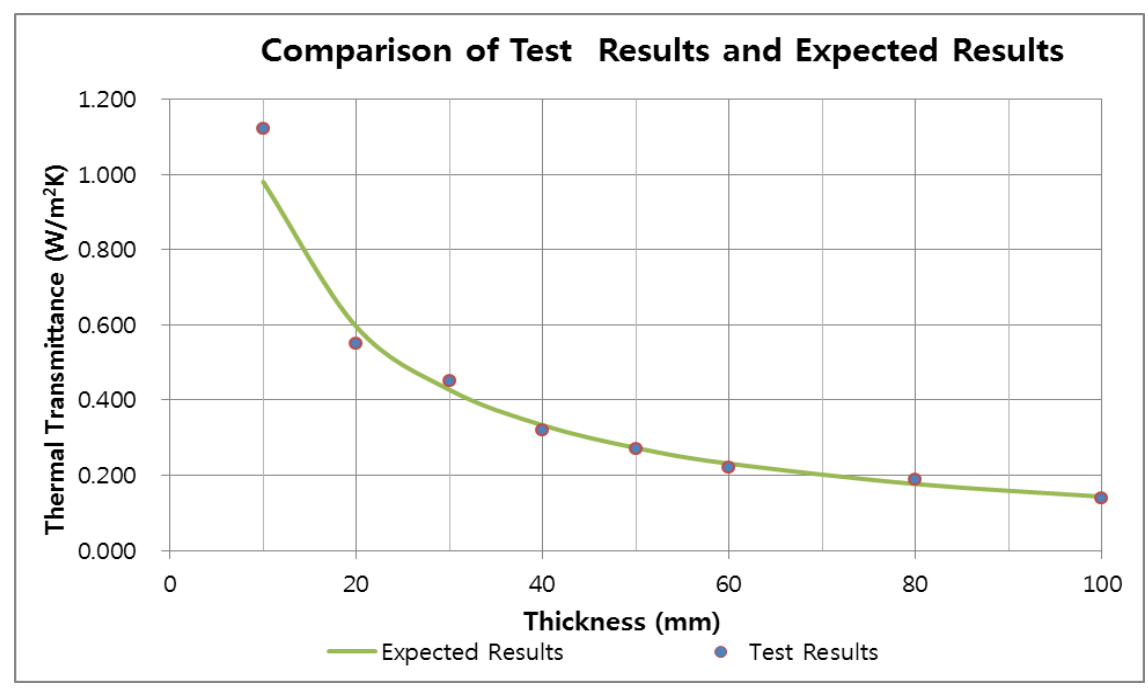

Figure 6. Comparison of the Test Results and Expected Results

Table 4. Expected Thermal Transmittance according to the Extracted Resistances

\begin{tabular}{|c|c|c|c|c|c|c|c|}
\hline & \multicolumn{2}{|c|}{$\begin{array}{c}\text { Thermal } \\
\text { Transmittance } \\
\left(\mathrm{W} / \mathrm{m}^{2} \mathrm{~K}\right)\end{array}$} & \multicolumn{5}{|c|}{ Insulation-Affecting Factor } \\
\cline { 2 - 9 } $\begin{array}{c}\text { Thickness } \\
\text { of } \\
\begin{array}{c}\text { Insulation } \\
(\mathrm{mm})\end{array}\end{array}$ & $\begin{array}{c}\text { Test } \\
\text { Result }\end{array}$ & $\begin{array}{c}\text { Expected } \\
\text { Result }\end{array}$ & $\begin{array}{c}\text { Extracted } \\
\text { Resistance } \\
\text { of Air Films } \\
\left(\mathrm{m}^{2} \mathrm{~K} / \mathrm{W}\right)\end{array}$ & $\begin{array}{c}\text { Assumed } \\
\text { Conductivity } \\
\text { Th/mK) }\end{array}$ & $\begin{array}{c}\text { Antracted } \\
\text { thermal } \\
\text { Resistance } \\
\text { of 10mm- } \\
\text { Thick } \\
\text { Reflective } \\
\text { Air Cells } \\
\left(\mathrm{m}^{2} \mathrm{~K} / \mathrm{W}\right)\end{array}$ & $\begin{array}{c}\text { Number } \\
\text { of 10mm- } \\
\text { Thick }\end{array}$ & $\begin{array}{c}\text { Expected } \\
\text { Thermal } \\
\text { Resistance } \\
\left(\mathrm{m}^{2} \mathrm{~K} / \mathrm{W}\right)\end{array}$ \\
\hline 10 & 1.12 & 0.971 & 0.360 & 0.050 & 0.470 & 1 & 1.0300 \\
\hline 20 & 0.55 & 0.588 & 0.360 & 0.050 & 0.470 & 2 & 1.7000 \\
\hline 30 & 0.45 & 0.422 & 0.360 & 0.050 & 0.470 & 3 & 2.3700 \\
\hline 40 & 0.32 & 0.329 & 0.360 & 0.050 & 0.470 & 4 & 3.0400 \\
\hline 50 & 0.27 & 0.270 & 0.360 & 0.050 & 0.470 & 5 & 3.7100 \\
\hline 60 & 0.22 & 0.228 & 0.360 & 0.050 & 0.470 & 6 & 4.3800 \\
\hline 80 & 0.19 & 0.175 & 0.360 & 0.050 & 0.470 & 8 & 5.7200 \\
\hline 100 & 0.14 & 0.142 & 0.360 & 0.050 & 0.470 & 10 & 7.0600 \\
\hline
\end{tabular}

\section{Comparative Insulating Performance of Low-Emissivity Insulation}

Low-Emissivity Insulation facing enough air space can be compared with other prevailing thermal insulation as shown in $<$ Table 5>. Its R-value is about $10 \mathrm{ft}^{2}{ }^{\circ} \mathrm{F}$ $\mathrm{h} / \mathrm{Btu}$ in. It has the same insulating performance as the Aerogel Blanket, which is very expensive and is developed as insulation for spacecrafts. Its R-value is almost twice as high as the general resistive insulation of XPS and EPS. 
Table 5. R-value of Insulations

\begin{tabular}{c|c}
\hline Insulations & $\begin{array}{c}\text { R-value } \\
\left(\mathrm{ft}^{2}{ }^{\circ} \mathrm{F} \text { h/Btu in }\right)\end{array}$ \\
\hline Vacuum Insulation Panel & $30^{\sim} 50$ \\
\hline Aerogel Blanket & 10 \\
\hline Low-Emissivity Insulation & 10 \\
\hline Urethane Foam Board & $6.8^{\sim} 8.0$ \\
\hline Urea Foam Board & 5.25 \\
\hline High density XPS & $5.0^{\sim} 5.4$ \\
\hline Low density XPS & $3.6^{\sim} 4.7$ \\
\hline High density EPS & 4.2 \\
\hline Rockwool & $3.0^{\sim} 3.85$ \\
\hline Loose-fill Type & $2.5^{\sim} 3.8$ \\
\hline
\end{tabular}

\section{Conclusion}

Based on the analysis of the contribution rate of the insulation-affecting factors of LowEmissivity Insulation, the following results were found.

(1) The resistance of the air films of Low-Emissivity Insulation is about $0.36 \mathrm{~m}^{2} \mathrm{~K} / \mathrm{W}$.

(2) The resistance of the reflective air cells of 10mm-thick Low-Emissivity Insulation is $0.47 \mathrm{~m}^{2} \mathrm{~K} / \mathrm{W}$.

(3) In case of an $80 \mathrm{~mm}$-thick Low-Emissivity Insulation facing air, whose thickness is over $30 \mathrm{~mm}$, the contributing rates of resistance for air films, conductive heat resistance, and thermal resistance of reflective air cells is respectively $6.4 \%, 28.4 \%$, and $65.2 \%$.

(4) The R-value of Low-Emissivity Insulation is almost twice as high as the general resistive insulation of XPS and EPS.

\section{Acknowledgement}

This work was supported by the National Research Foundation of Korea(NRF) and the grant funded by the Korea government(MEST) (No. 2014R1A1A4A01005565).

This work is the result of 2012's Industrial Technology Innovation Project supported by the Ministry of Trade, Industry \& Energy.

\section{References}

[1] Y. C. Kwon, Y. O. Kim and G. Y. Lee, "An Innovative Low-Emissivity Insulation Developed in Korea", ASTM STP, vol. 1574, (2014), pp. 101-118.

[2] Y. C. Kwon and Y. O. Kim, "A Study on the Development of a High-Efficiency Low-Emissivity Insulation", Journal of KIAEBS, vol. 4, no. 3, (2010), pp. 89-95.

[3] http://passipedia.passiv.de/ppediaen/planning/thermal_protection/external_walls/passive_

[4] house_suitable_wall_systems.

[5] Y. C. Kwon, "Insulation Applications for Buildings in Korea", Proceedings of 7th Global Insulation Conference, (2012); Latvia.

[6] E. K. Rhee, “Architectural Environmental Planning”, Taelim Publishing Co.,

[7] ASHRAE Handbook-Fundamentals(SI), (2013), pp. 26-20

[8] S. C. Lee and D. C. Shin, "Performance Comparison of Genetic Algorithm and Trial and Error Method in the Member Size Optimization”, Journal of Architectural Institute of Korea vol. 25, no. 10, (2009).

[9] Y. C. Kwon and K. M. Kim, "A Study on the Insulating Characteristics of Low-E Insulation depending on heat transfer paths and materials", Workshop on Architecture, (2015); Korea. 